\title{
THE AFRICAN ELEPHANT
}

\section{PART I}

IN common with other species of animals whose range is great, comprising most of the continent south of the desert zone (Ethiopia), the African elephant exhibits considerable local variation as regards size, form, especially of the ears, curvature of the tusks, and character of the ivory, etc. Hitherto, live examples available for study have been too few, and dead material too meagre, to permit of any satisfactory definition of local types or races by the systematic zoologist, but such attempts as have been made in this direction have so far been based upon the characters of the external ears, as being thought to be the most convenient for the purpose.

According to one writer on Zoology (Matchie), who had, however, little but museum material for examination, the four most diverse types of ear are as follows: (I) Cameroons or West Africa, nearly oval; (2) Addo Bush or East Cape, somewhat square; (3) Masai or East African, small and triangular (equilateral); (4) Abyssinian or Sudan, large and triangular (acute). Ear characters, however, really amount to very little as a guide to any useful classification.

Two Distinet Speeles.

A careful study of this subject and a good many years' experience with elephants in the Congo, Cameroons and Nigerian forests, compared with similar experiences in more open regions in the Uele (Congo), Sudan and Uganda, enables me to suggest a much more definite and practical grouping of the African elephants, viz. under (a) Forest, and (b) Bush or grass animals. The former group would contain No. I of the above types or races, and probably No. 2, the latter Nos. 3 and 4 .

These two great groups are quite distinct, and their individual herds do not mix or mingle, the forest elephant rarely if ever coming far out into the open country and vice versa. Only 
where the continuity of the forest becomes broken, or merges gradually into bush, or where there are marginal forest gardens to be raided, are individual members or herds of the two groups to be found in close proximity to each other. It would seem probable that the big bush elephant most nearly represents the ancestral stock, whether indigenous or introduced, and that the smaller forest type is the more specialised, owing to its long existence as a forest animal. Both are derived, no doubt, from the same stock, but not the one from the other, for there is no gradation between the two; their specific differences are well marked and constant. The complicated evolution of Africa and its fauna, and the meagreness of our knowledge on the subject, make the whole matter a difficult one. This division, however, into two distinct species, forest and bush, has its parallel in other animals; for example, the buffalo, the little red animal of the Ituri forest and Western Africa being a highly specialised specific type, while the big black Cape buffalo retains its resemblance to the original stock. Even in man we have a parallel, the pygmy tribes of the Congo forests being doubtless the most highly specialised form of African man, while the big black negro living beyond the forest more nearly resembles his ancestral forbears.

\section{The Forest Elephant.}

The well-known bush elephant of East Africa, Abyssinia, the Sudan, and the Uele region of the Congo, will need no description here. The forest elephant, on the other hand, is far less well known, and has a much more restricted range, being confined to what is left of the great rain-forests of the equatorial belt, now lying almost entirely to the westward of the Albertine or Western Rift. Size is the main outstanding difference between the two. Unfortunately, most of my measurements have been lost with the field-book recording them, and the only shoulder heights to be found in the pages of my journals are the following: From sole of forefoot to shoulder-

Group (a). No. I. $2 \mathrm{~m} .95 \mathrm{~cm}$. (9 feet 7 inches);

" "No. 2. $2 \mathrm{~m} .35 \mathrm{~cm}$. ( 7 feet 8 inches);

Group (b). No. 3. $3 \mathrm{~m} .40$ c.m (Ir feet I inch);

" No. $4.3 \mathrm{~m} .30 \mathrm{~cm}$. (ro feet 9 inches). 
No. I was a big and old elephant carrying 72 kilos ( 159 lbs.) of ivory; No. 2 a younger but mature animal carrying 45 kilos (99 lbs.); No. 3 a middle-aged bush elephant with 72 kilos (I59 lbs.); and No 4 a very old animal with 95 kilos (209 lbs.). It will be seen that these four measurements show an approximate average difference in height between the two groups of 2 feet 3 and 4 inches, and from the recollection of many other measurements of elephants I have shot, both in forest and open country, I am sure that the real average difference between the two species is even greater. The smallest race of elephants is probably to be found in the Cameroon forests of the Congo basin, and possibly in the forests and swamps of Lac Leopold II in nearly the same region; the largest in the bush regions of Abyssinia, the Anglo-Egyptian Sudan, and Upper Congo (Uele).

Of other differences the most marked are, the more profuse growth of bristles on most parts of the body and limbs of the forest animals, and the longer hairs on the chin, under-lip, and at the extremity of the tail, those on the chin frequently measuring as much as II or I2 inches. Those on the upper third of the trunk are 4 to 6 inches long; whilst the rest of the trunk is so covered with short stiff bristles, protruding half an inch or more, that only the hand of a native can handle it. The belly and most parts of the body are thickly covered with short bristles in the same way. The external ears, for the same reason also, are difficult to handle. The thick posterior bristles of the laterally flattened, almost spatular-like, end of the tail may be more than $I 6$ inches in length. The forest elephant, in fact, like the little forest people and the forest hog, is remarkable for its hairiness.

The skin, as the result of the surroundings in which the animal lives, instead of being blackish-grey, hard and almost horny, as in the grass elephant, is creased and furrowed, clean, black and supple, almost rubber-like. The basal foot or so of the tail is enlarged and bulbous. The external ears are enormously large and oval, or triangular-oval, with the lower lobe more or less pointed. The ears are never, as far as I am aware, long and acutely triangular, as are some of those commonly seen in British East Africa. As much as I8 
inches of the upper lobe falls inward, but still leaving the upper part of the ear standing a foot or more above the neck. Both groups are perhaps similar in this latter respect.

Compared with those of the grass and bush country animals, the tusks are invariably straighter, thinner, smaller and consist of harder ivory. Forest animals with tusks weighing roo lbs. or over are very scarce. Owing to the density of the ivory, forest tusks weigh more than the same sized tusks from the grass country, and the ivory, being much harder, is of less value upon the market.

\section{Podtion of Tush in Forest}

The tusks of forest elephants are usually fairly divergent at the tips, instead of being, as one might expect, the opposite. I have recorded in my notes distances of 34 inches and 37 inches between the tips. When pushing his way through thick undergrowth an elephant carries his tusks vertically, as close to his knees as possible, forcing a passage with his forehead and his nose-the protruded basal portion of the trunk-while the mobile tip is used to lift creepers and branches out of the way or guide them under his feet. The first part that one sees of an elephant coming out of thick undergrowth or grass is the protruded basal portion of the trunk. Even when standing at ease the tusks are held more or less vertically, while the grass elephant, on the other hand, carries his at all times much more horizontally in front of him. Twenty years ago I saw elephants in the Nile Provinces of Uganda with tusks so long that they could not possibly have been carried in any other way than almost horizontally in front of them. For such animals it would have been a physical impossibility to have ever entered forest country.

\section{Pygmy Elophenth.}

By reason of his long residence in dark, sunless, moist surroundings, and perhaps his scantier and less varied diet, the forest elephant has become a pygmy race, two or three sizes smaller, as it were, than his big brother outside the forest. Whether or not, as has been frequently asserted, there exists in Africa a real pygmy race of elephants no more than half the 
size of the bush race, still remains to be proved. In spite of reputed specimens occupying space in the cases of at least one museum, there is as yet in my opinion no sufficient evidence of the existence of such a species in Africa. Many and varied are the tales of the natives, especially in the Uele district of the Upper Congo, of herds of pygmy elephants which are said to frequent the forested and swampy banks of the Bomokandi and Nepoko rivers, and many times have I come in contact with these herds and found nothing more exciting than family parties of ordinary forest elephants consisting largely of young animals. The native is cute enough to have noticed that of recent years the white man is always interested in reports of pygmy elephants, and he colours his tales accordingly. Such fables are no more to be relied upon than those relating to fourtusked elephants, or to living "Brontosauri." There may be single examples of dwarf or very small elephants here and there living with the herds of larger ones, though such sports must be extremely rare. I have on one occasion seen some such animal in the Uele region, near the Nile-Congo watershed. It was in a grass country, a considerable distance from any large forest area, late in the hot weather, when most of the long grass had been burnt off. I had been out since early dawn, and shot only a wart-hog, when towards midday we came upon.fresh tracks of elephant, easy to follow on the burnt and blackened ground. An hour's tracking and then, in an unburnt area, we came up to a herd of seven or eight, two of which seemed likely to carry good ivory. Owing to the direction of the wind, and the scattered way in which the elephants were standing, I was a long time getting near either of the two tuskers, but at length I succeeded in killing one of them with a double heart shot. To my intense disgust I discovered that one tusk was broken off about eighteen inches from the gum, an old injury. While I had been approaching him there walked across an open space, where the grass was trampled flat, in full view of myself and my two men, a very small elephant, little more than six feet in height, probably, I think, a female, with a pair of very long, thin, straight and actutely pointed tusks, which the grotesque little animal carried quite vertically, nearly touching the knees, while the tips 
barely cleared the ground. The long tusks in comparison with the size of the animal, the attitude of the head, and a stilted kind of walk, possibly due to the length of the ivories, so astonished me that from the comer of my eye, although I was concentrating upon the tusker close in front of me, I made a clear mental negative of the scene which has never dimmed.

Dearease in Numbers.

Elephants still exist in enormous numbers in many parts of tropical Africa. If a census could be taken I should not be surprised to learn that their actual numerical decrease during the last thirty years had been but very little. The great herds of several hundred animals, once so common, are of course now never met with, for owing to the widespread introduction of firearms, the continual demand for ivory, the systematic opening of roads and caravan routes, and the spread of cultivation, the large herds have been scattered, their feeding-grounds are restricted, and individuals and family parties are kept perpetually on the move, or confined to uninhabited areas, with the result that the decrease in numbers is more apparent than real.

On the other hand, the number of big tuskers with ivory over $75 \mathrm{lbs}$. in weight has no doubt very greatly decreased in recent years, and so also has the number of medium tuskers of, say, 50 lbs. and over, but to a lesser extent. When I first knew Uganda in I902 nearly everyone succeeded in shooting the two tuskers allowed him upon his licence each year, one or both of them frequently being hundred-pounders. Even tusks in the region of 150 lbs. were not of rare occurrence. Now-a-days one must go much further afield, and hunt for months, to have a chance of getting anything over Ioo lbs. in weight. The biggest and heaviest pair of tusks that ever fell to my lot, now a good many years ago, scaled I44 lbs. and I46 lbs. The heaviest I have shot since I 910 weighed $x$ I 9 lbs. and $\mathrm{r} 2 \mathrm{olbs}$. when fresh.

Tuskiess Males.

Opinions all seem to agree that in Africa tuskless males are rare. I only remember to have seen one, and that I had 
the misfortune to shoot in the Lado Enclave. I had heard elephants during the night, and with the help of a pathway, and accompanied by a native gun-bearer, I managed to get near them before daylight. Later, as I was getting up close, I had the rising sun directly in my eyes, and my spectacles, always a trouble, became clouded with perspiration. Through the grass I made out what appeared to be a big fellow with fairsized tusks, standing side on to me, thirty yards away, while a smaller one, also with good tusks, stood a little to my left. I had scarcely made out their positions when they got our wind or heard us, and were in the act of moving off as I hurriedly fired at the big one in front of me, taking the heart shot, and giving him both barrels. To my utter astonishment both the animals went off at top speed and kept going, while a third and smaller one, whose presence I was not aware of, and which apparently had been standing close alongside the big tusker, and on my side, after a rush of fifty yards came down with a crash. I was seldom more astonished or chagrined, and my ill luck seemed the more overwhelming when I discovered that the beast I had killed was tuskless. There was no appearance even of the tusks ever having developed. Those two cartridges cost me $\ell^{10}$, the amount which at that time had to be paid to the Sudan Government for each elephant shot on one's licence.

One-Tukern.

A bull with one tusk only is a comparatively common sight, and I remember once in the Lado Enclave finding two onetuskers in a herd of eighteen. We came on fresh tracks about 9 a.m., and two hours later got up to the berd standing in fairly high bush on the brow of a rise. There was a pretty strong wind blowing in our faces as we approached them, and quite a cloud of bee-eaters and other birds noisily hawking for insects above them. They were in a crescent formation facing the wind, and with their backs towards us we could see nothing of the ivory. After a time, however, by climbing a thorn bush, I made out that what seemed to be the two biggest animals were on the right horn of the crescent. So, making my way round through the grass in that direction, I again carefully approached them from nearly in front, with the wind, fortu- 
nately a steady breeze, now blowing almost across me to them. From a friendly ant-hill I was surprised to see that both the first two elephants were one-tuskers, the second from me having the bigger tusk, long and unusually straight. There was no time to be lost, for they might get my wind at any moment. A few steps nearer and I was able to put in a carefully placed shoulder shot. I should have liked to have given him the second barrel, but I was too near, and they were nearly all facing me. If the whole formation had charged in my direction, as was not unlikely, I should have found myself with an empty rifle. They, however, scattered, my wounded one with them, and while looking after myself I lost his direction. A hunt round amongst the many tracks soon revealed a bloodtrail, but not till late in the afternoon did we again see our elephant, savaging the branches of a tree in open bush. He was evidently in a bad way, a dangerous animal to go near, but with some creeping and crawling against a steady wind I was able to make an end of him with a head shot. When dry that tusk scaled 79 lbs.

\section{Broken Toiks.}

An elephant with one tusk broken, or the tip gone, is quite a common sight, usually the result of digging in hard ground, falling amongst rocks or in prizing up the roots of trees. I remember meeting with rather curious presumptive evidence as to the cause of a broken tusk, at a forest camp a little west of the Semliki valley. I had been on the tracks of two elephants for several hours, and at last heard a " blow," a noise to which one's hearing becomes very acutely attuned in forest work, and which always gives the animals away when within a few hundred yards. It is the elephant's way of clearing his trunknose and testing the breeze, if there is any, while he is busy feeding, or, in fact, at any time. We eventually got up to the two elephants, which were pulling down branches and making a great " to-do," in a tangled mass of creepers and underwood, where it seemed impossible to get a view of them from any direction, try as we would. One of my men-I had two with me that day-at length climbed a tree and discovered a small watercourse, and by making a détour and wading along this, we at last got close up. Then, after waiting for what seemed 
to be an age, one of the brutes changed his position to nearer the bank, and presently I got a view of what appeared to be a fair-sized pair of tusks as the animal reached up with his trunk. I was scarcely likely to get a better chance of a shot, for the place was a most impossible one, so I took the head shot, the only shot available, at about twenty yards, being, however, by no means sure of $\mathrm{my}$ aim, as regards place and angle of direction.

At the shot the elephant collapsed, crashing down the bank, but soon had his legs under him again, and was on his feet, evidently very much dazed. His stern was directly towards me, and in full view, for his fall and struggle had cleared quite an open space, so, rather than risk his being only slightly wounded and turning round upon me, for there was no getting away in such thick underwood and tangle, I gave him a tail shot, and reloaded again quickly. This shot should be in the middle line just above the root of the tail, and may be very useful when no other is possible. It should only be given from directly behind and close up. Though the animal may not fall, the hind limbs are sometimes put completely out of action, for it is at this point on the back that the great nerves supplying the hind legs branch off from the spinal cord. In this instance, after receiving the shot, slightly misplaced, the beast went only two or three short steps, and, turning half round, gave me a chance to move to a position from which I could put in an effective heart shot. Climbing round to his head to examine the ivory after he was down, I was disappointed to find that one of his tusks was minus about eighteen inches of its tip. The other scaled only 59 lbs.

As a rule it is extremely difficult to get a sufficiently clear view of an elephant's tusks to make a correct estimate of their size and weight before shooting the animal, unless he is out in the open, which is not often the case. One is so intent upon the beast's movements and actions, and upon mancuvring to get to the right position, and then to get in an effective shot, that to pay sufficient attention to the ivory, even if there is a possibility of seeing it, is far from easy under the circumstances. 


\section{A Staked Elephant.}

When I shot this elephant I was camped with the Chef de Poste, Mboga (a station since closed), near the edge of the Ituri forest, and what with askaris, his porters and mine, and several chiefs and attendants, I had nearly seventy persons in camp. Except our immediate attendants all migrated to the dead elephant, and when we moved on twenty-four hours later there was not a great deal of it left for the women and children, who came in swarms, to carry away to their villages in the Semliki valley. During the chopping-up process an interesting discovery was made. Lying within the belly was found the business end of a hard-wood stake, some sixteen inches in length, and at the base over four inches in thickness, at the tip of which was fixed an iron spear-head. Except for a sinus with thickened edges, the wound in the abdominal wall, strange to say, was healed. From this circumstance, and the fact that the end of the broken tusk was much worn down, I judged that the two injuries had occurred about the same time, and consequently it was not difficult to reconstruct in one's mind what had happened, and to imagine that, having fallen into a hidden pit-trap, the struggles of the beast in digging himself out may have fractured the tooth, if it was not actually broken in the fall, which is very probable.

\section{Drop-10g Traps.}

Some of the tribes on the Semliki side of the Ituri forest are adepts at setting drop-logs traps, and they manage to kill quite a number of elephants, even the oldest and wisest of tuskers. These murderous traps consist of a heavy log of wood, perhaps six feet long and nearly a foot or so thick, to the lower end of which is fitted a strong short-bladed spear. The log, with its spear pointing downward, is raised vertically to a height of sixteen or eighteen feet above an elephant path, usually at a spot where it passes between two trees standing close on either side of it. The drop-log is held in position by a thick forestmade creeper rope passed over a branch, or over a crossbar conveniently placed for the purpose. At the end of the rope is a wooden peg, which is ingeniously adjusted about a foot from 
the ground, between two stakes driven into the earth on one or other side of the track, or between two saplings. Stretched across the pathway is a finer rope, one end of which is also attached to the peg which keeps the whole contrivance in position, and upon the fine adjustment of which depends success. Any animal tripping over the trigger-rope unhitches the peg and instantly releases the log and spear. These traps are usually built over elephant paths leading out of cultivated areas, and are kept unset with the log and spear in position, until, on some suitable night, when the elephants raid the crops, the natives go out and set them by taking away some safetycatch, so that when the herd retires to the forest at dawn there is pretty sure to be a casualty. A rude and camouflaged palisading is sometimes constructed, by felling small trees and bending down saplings for many yards on either side of the trap, so as to guide the robbers towards it, if they happen to stray from the pathway.

\section{Right- and Lait-Handed EHophents.}

I have no doubt that an elephant in search of roots in soft ground uncovers them by scraping with a forefoot, and then prizing them up with his tusks, as described by my old friend the late Captain Selous. They are able to use their tusks with extraordinary precision, though not with the delicacy with which they can manipulate their trunks. I once watched an old tusker in a sweet potato patch rolling over the masses of leafy runners until he came to the main stem of each plant, and then, by inserting a tusk, always the same one, his working tusk, he turned out the white tubers as neatly as any native woman could have done with a stick. An elephant is as much rightor left-handed with his tusks as a human being with his hands. Sometimes it is the right, sometimes the left that is the working one. I have crouched in the hollow formed by the upturned roots of a fallen tree and watched two young elephants, only a few feet away along the trunk, make gashes in the bark with their sharp-pointed tusks, prize up a piece, then pull off a long strip with their trunks with the utmost ease. An African elephant is able to get quite a tight grip with the two finger-like processes at the tip of his trunk. 


\section{Treo-Felling.}

Elephants are very fond of chewing the bark of acacias, stripped off in this way, probably for the astringent effect of the tannin which it contains. Distributed practically throughout the whole of the bush regions of tropical Africa, this tree has a heavy top and surface feeding roots, and it is not surprising that by simply pushing with his forehead and his "nose" the protruded basal portion of the trunk, with occasional assistance from a forefoot, and getting the tree on the swing, he is able to bring it down. He will sometimes fell other trees, even deep-rooted ones, forty or more feet in height, by adopting more or less the same procedure, after exposing and partially severing a main root with his tusks. He will spend hours of labour on the work, all for the sake of the small sweet fruit which the tree bears.

In the old Lado Enclave, now a portion of the Mongalla province of the Sudan, I narrowly escaped serious injury by getting in the way of a tall tree felled in this fashion. Unable to sleep one night, with a noisy lot of porters too close to me, I got up about 3 a.m., and, my gun-bearer being down with fever, I called a porter and set out in the clear bright moonlight along the path by which we had come the previous day, and on which I had noted comparatively fresh tracks of many elephants. Ten minutes from camp we heard elephants, but after listening awhile decided that they were a family party, and so we left them alone. Half an hour later we were halted by a slight noise, then came the crack of a ribband of bark being forcibly torn away, and, as we listened, we could hear a movement of bushes, and the involuntary intestinal gurgles always to be heard when close to the great-bellied beasts. Our ears soon told us that there were two, not many yards from the pathway, and evidently big fellows. Retracing our steps, we sat down and waited for daylight; and as we sat contemplating the glistening moonlit stillness, I marvelled at the ability of the elephant to pass through long grass and bushes at night, feeding all the while, so silently. When light permitted, I picked up the tracks as they crossed the path, and with the man behind me, followed them for two hours with scarcely 
a fault. Then I caught sight of the pointed top of a tall tree being violently agitated, and I knew we were close up. Testing the wind with a little wood-ash I always carried for the purpose in a pocket of my shooting waistcoat (I never wore a coat), I crept up nearer, and got a view of a very big elephant, with a grand pair of tusks, intent on pushing down a tree. So absorbed was I in taking in all the details of place and circumstance, and the possibility of reaching a small ant-hill from which I could get a clear shot, that I failed to keep an eye on the tree, now on the point of crashing, and, as I thought, well to my inght, but before I could get out of the way I was involved in the downfall. Collecting my rifle and crawling out, feeling rather knocked about and ill-treated, I discovered the elephant still in the same position examining the roots he had exposed; so, making for the ant-hill as best I could in my crippled condition, I put in two heart shots, one after the other quickly, for the tusks were well worth any risks. There was a rush of fifty yards, a feeble attempt to catch hold of a branch with his trunk, a sinking of the hindquarters, and over he rolled. His chum, also a big elephant with heavy tusks, stood his ground a few yards away, till the crash came, and then, realising the serious state of affairs, was off like a railway train before I could pay him any attention, and I daresay he never stopped till he was ten miles away.

Cuthbert Christy.

(To be continued) 